\title{
The Analysis of The Changes In The Interior Design Of Houses Due To The Westernization Movements In $19^{\text {th }}$ Century In The Ottoman Empire
}

\author{
Orhun Polat \\ IELEV Private High School, TURKEY
}

\begin{abstract}
Westernization movements during the $19^{\text {th }}$ century caused great changes in interior design of Ottoman houses. It is a question of debate whether the cited changes have been carried forward to our day. The interior design features of traditional ottoman houses prior to Westernization period were analyzed as methodology primarily in order to answer this question discussed within the purview of the study. Subsequently, the interior design features of the Ottoman house influenced through the $1^{\text {th }}$ century Westernization movements and the interior design features of the $21^{\text {st }}$ century Turkish houses were determined. At the next stage, interior designs of houses belonging to these three phases were compared in terms of spatial organizations, usage of furniture and design styles. At the last stage of the study, it was determined if the changes caused through the $1^{\text {th }}$ century Westernization movements in the interior design of the Ottoman house were preserved in the $21^{\text {st }}$ century Turkish houses in line with the results obtained from the comparisons made to this end.
\end{abstract}

Keywords: Westernization in the $19^{\text {th }}$ century, traditional Ottoman house, $21^{\text {st }}$ century Turkish house

\section{INTRODUCTION}

The $19^{\text {th }}$ century is a period when the Ottomans have experienced major cultural changes under the influence of the West (Hergon and Motika, 2000:139). "Major reforms have been put into practice following the declaration of the Tanzimat Fermanı (Imperial Edict of Reorganization), Islahat Fermanı (Imperial Edict of Reform), First Constitutional Period and after the first constitution has entered into force" (Karabulut, 2016:50). These reforms also have covered numerous different areas (Lewis, 2002:100). This quick change which has taken place in the Ottoman Empire has also showed itself in houses which are indispensable for everyday life (Artıkoğlu, 2011:49). The places where the effects of Westernization movements are observed firstly are the lifestyle of the prominent people of the society and interior design of the houses according to Demirarslan (2011:213). As a matter of fact the houses in those periods have become symbols which determine the economic level of their users in addition to their status in the society for the first time (Demirarslan, 2011:211). It is a question of debate if the effects of this great change in interior spaces of the houses still continue in our day. As such, the question to be covered within the purview of the study has been determined as: "Do the effects of the $19^{\text {th }}$ century Westernization movements of the Ottoman Empire on the interior design of houses at that period still continue in the $21^{\text {st }}$ century Turkish houses?"

Interior design features of traditional Ottoman house prior to the Westernization period will be explained at the first stage in order to be able to reply this question of the study. Subsequently, the interior design features of the Ottoman house influenced through the $19^{\text {th }}$ century Westernization movements and the interior design features of the $21^{\text {st }}$ century Turkish houses will be determined. At the next stage, interior designs of houses belonging to these 
three phases will be compared in terms of spatial organizations, usage of furniture and design styles. At the last stage of the study, it will be determined what the effects of the $19^{\text {th }}$ century Westernization movements have made on the interior design of the Ottoman houses and whether these effects continue in contemporary Turkish houses of our day.

\section{INTERIOR DESIGN OF TRADITIONAL OTTOMAN HOUSES PRIOR TO 19TH CENTURY WESTERNIZATION MOVEMENTS}

Traditional Ottoman houses are described as "houses which feature the form and plan characteristics in line with the life culture and customs of the Turkish family and which have answered the needs of the Turkish people for centuries" (Kuban, 1976 cited in Bozkurt, 2013:38). "This type of house comprises two main spaces called rooms and sofa (hall/long room)" (Küçükerman, 2007 cited in İnce, 2013:5) as can be observed in the schematic plan drawings in Figure 1.

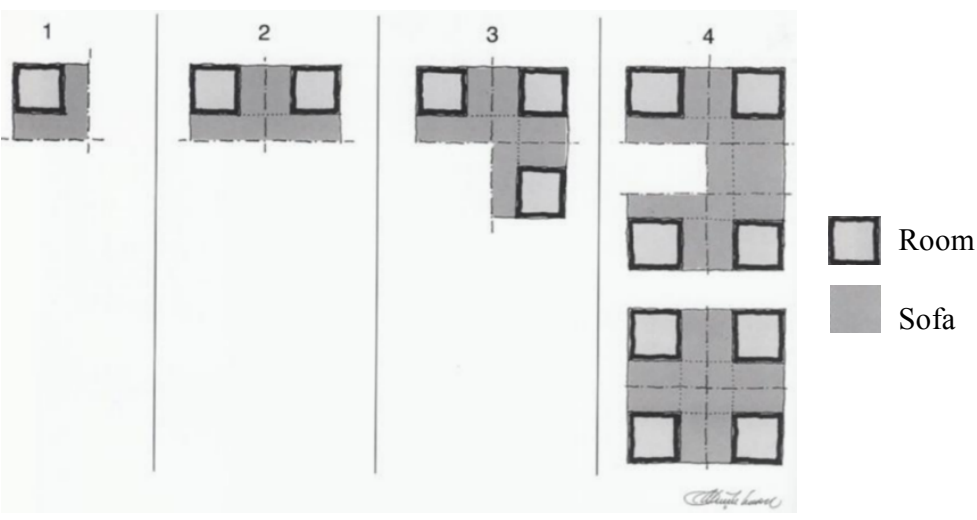

Figure 1. Development order in the relation of the rooms with each other and with sofa (hall/long room) in traditional Ottoman houses (Küçükerman, 2007 cited in İnce, 2014: 31)

"Sofa is the common space where inter-room relations are achieved. The doors of all rooms are opened to the sofa. This space, in addition to being a circulation area, is a sitting and meeting place at the same time" (Küçükerman, 1985: 53, Hacıbaloğlu, 1989:19 cited in Yıldırım and Hidayetoğlu, 2009) (Image 1).

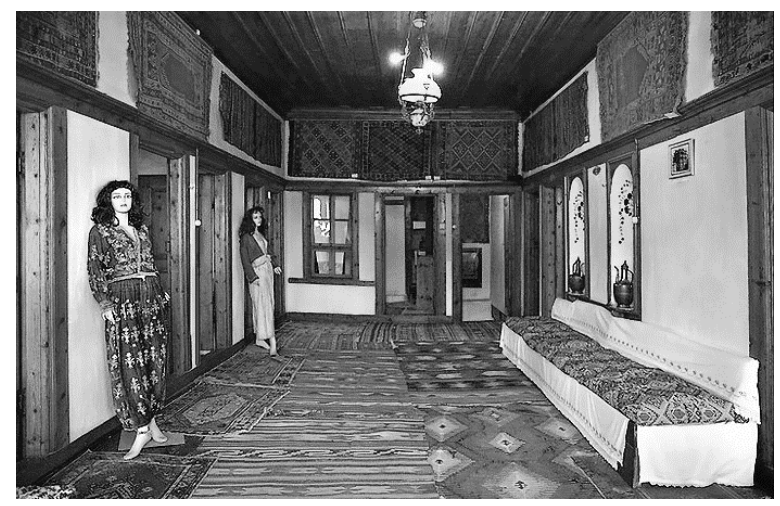

Image 1. Sofa (hall/long room) (Laf Sözlük (Laf Dictionary), 2018)

The room contains almost all of the functions of a house (Artıkoğlu, 2011:53). This space is designed to fulfill all kinds of activities such as sitting, resting, preparing food, cooking, eating, heating, sleeping and working (Hacıbaloğlu, 1989: 21 cited in Ylldırım and Hidayetoğlu, 2009). Household eat at the floor tables (Demirarslan, 2011:211). When the room in which household sits during the daytime, becomes bedroom by taking out the beds from yüklük (closet) (Ylldırım and Hidayetoğlu, 2009) (Image 2). 

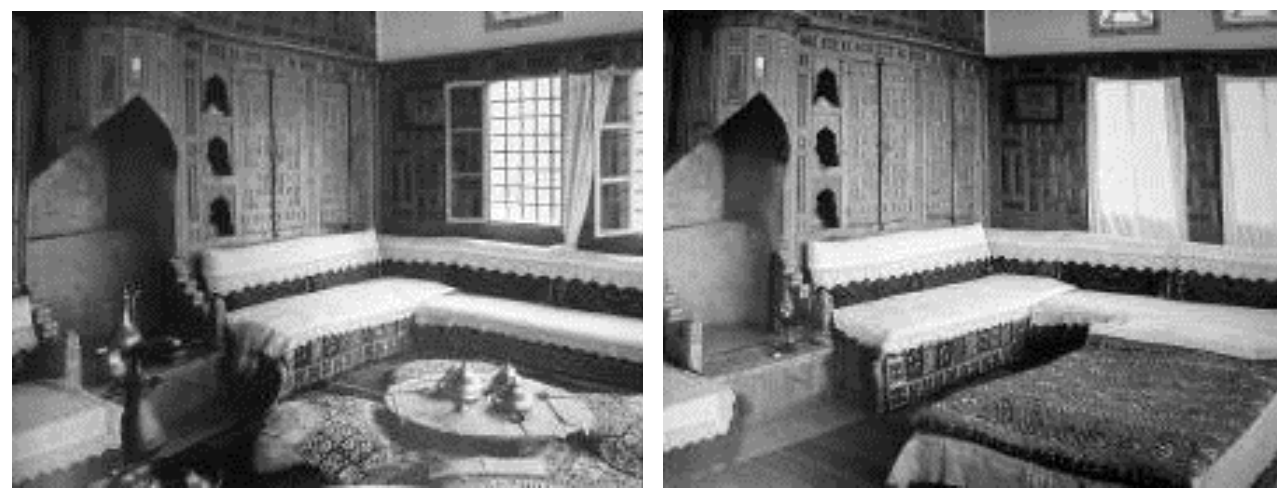

Image 2. Day and night use of the room (Günay, 1998:171 cited in Yıldırım and Hidayetoğlu, 2009)

"The hearth has a central position in the room while both sides of the hearth is surrounded with sedir (ottoman). The sedir is next to the window. There is no movable furniture in the interior. Sergen (high shelves), niches, yüklük and shelves on the walls are planned in the best way to meet the daily storage needs" (Burkut, 2014:60). The interior planning is made such a way that the center of the room is always left free (Artıkoğlu, 2011:53). In the lower part of the yüklük, there is a small space for ablution named as yunmalık/gusülhane (bath) which is separated by a cover (Ylldırım and Hidayetoğlu, 2009; Demirarslan, 2011:211). The toilet is outside the house in the yard.

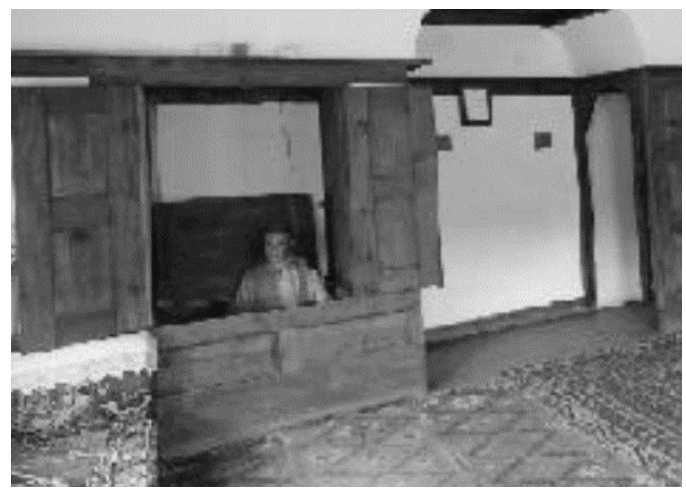

Image 3. Yunmalık/Gusülhane used as for ablution in the rooms (Bozkurt Azezli, 2009:38)

"One of the rooms is called as the Baş oda (main room) and is special because here the head of the families host the guests and makes meetings. Baş oda is usually one of the corner rooms and is the most important room of the house. Its interior arrangement is also similar with other rooms disregarding these events" (Hacıbaloğlu, 1989:22-23 cited in Yıldırım and Hidayetoğlu, 2009) (Image 4).
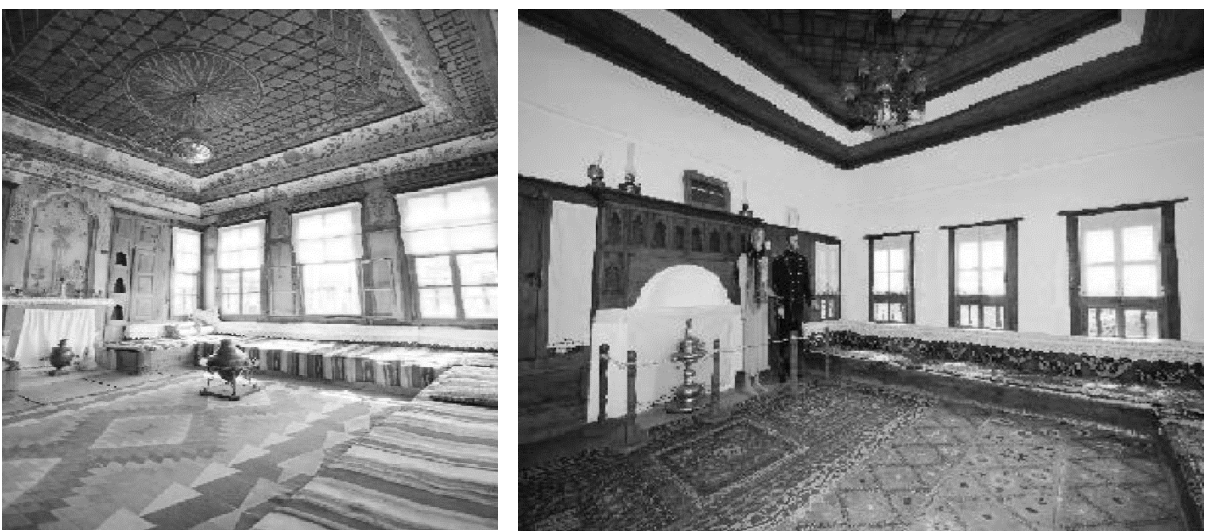

Image 4. Baş oda (The Most Important Room) (Bozkurt Azezli, 2009:64) 
The style which was outstanding in the interior arrangement of the traditional Ottoman house before the Westernization period shows great similarities with the modern architectural movement. Bektaş (2001) has said the following as regards the issue: "Interior design principles of the Ottoman house have not conflicted at all with the principles of the modern architectural movement which have influenced the Western architecture from the beginning of the $20^{\text {th }}$ century" (Bektaş, 2001:52 cited in Göğebakan, 2015: 45).

\section{INTERIOR DESIGN OF THE OTTOMAN HOUSE UNDER THE EFFECT OF THE 19TH CENTURY WESTERNIZATION MOVEMENTS}

"The Ottoman house started to lose its original position with the influence of $19^{\text {th }}$ century Westernization movements. Interior space plan has changed and goods and furniture imported from the West have become widespread" (Bozkurt, 2013:46). "The rooms in the house have been replanned according to specific functional groups. In this way, the rooms, in which different functional activities were carried out together in the traditional house, gained an identity by being divided into single activity (such as hall, living room, dining room, bedroom, bathroom, kitchen etc.)" (Artıkoğlu, 2011:53; Demirarslan, 2011:218).

"Instead of the multifunctional sofa which connected the spaces to each other in the traditional houses, corridors and halls began to be planned. In this way, the corridor in the Turkish houses turned into a border separating the service spaces facing the backyard and the rooms opened to the street" (Demirarslan, 2011:218). The area named vestibule, which is located at the entrance of the house, has been formed as a small room which is also accepted as a cloakroom and a dress room (Meriç, 2000:431 cited in Artıkoğlu, 2011:53). "Antechamber is the part between the vestibule and the big hall in large houses. It has the function of waiting room in front of the big hall" (Artıkoğlu, 2011:53). Only couchs, armchairs and chair groups are used in furnishings of antechambers (Meriç, 2000:436 cited in Artıkoğlu, 2011:53).

Use of furniture such as consoles and buffets under the influence of Westernization has led to creation of the halls in the houses which have replaced Baş oda of the traditional houses (Demirarslan, 2011:214). The couchs, and armchairs used in lieu of sedir and the table in the center, chairs and coffee tables have become defining elements of halls and approach of usage of groups and sets in furniture use in the space has become significant (Demirarslan, 2011: 215) (Figure 2).
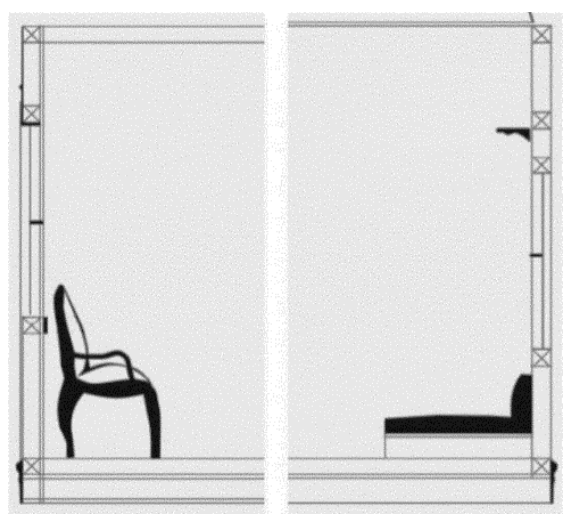

Figure 2. Armchairs and couchs used in lieu of sedir under the Westernization effect (Bozkurt Azezli, 2009:91)

The existence of a separate room for eating is another significant change in $19^{\text {th }}$ century Ottoman house (Artıkoğlu, 2011:55). A dining table, chairs and a buffet which is a part of this furniture group were started to be used instead of the floor table in this room (Demirarslan, 
2011:219). A bedstead instead of a floor bed, wardrobe, nightstand and chest of drawers were used instead of yüklük while chairs or armchairs were used for sitting in the arrangement of the bedrooms (Artıkoğlu, 2011:55; Demirarslan, 2011:219). In these rooms there are also washbasins and a place for ablution (Artıkoğlu, 2011:55). It is also observed that separate rooms are allocated for children in addition to separate bedrooms (Demirarslan, 2011: 218). The toilet located in the yard has been moved into the house as of $19^{\text {th }}$ century (Göğebakan, 2015:52). "The Turkish style toilet system has been replaced by European style toilet. Over time, a new solution has been produced by attaching a bidet nozzle to the European style toilet and by combining the traditional usage habits with modern hardware" (Demirarslan, 2011:215). Algan (2006: 106) has stated the following as regards the styles which have stood out in the interior arrangement with the influence of Westernization: "Usage of Baroque, Regence, Louis XV, Louis XVI, Rococo, Neo classic, Orientalist and Art Nouveou has started in furniture such as dining table, chair, bedstead, wardrobe, dresser etc. in $19^{\text {th }}$ century for the first time in houses".

\section{INTERIOR DESIGN IN 21 ${ }^{\text {ST }}$ CENTURY TURKISH HOUSES}

Tuzlu Erol (2013:48-51) has detected that when analyzing $21^{\text {st }}$ century Turkish houses in terms of space organizations they consist of kitchen, living room, parent bedroom, toiletbathroom, hall-entrance-circulation areas. Furthermore, it is observed that living room, dressing room, children's room, guest room, maid room, bathroom to all bedrooms, study room, TV-cinema room, pantry, dining room, cleaning-laundry room, fitness room, common study room and hobby room are added as income level increases (Tuzlu Erol, 2013: 75-118). It is observed that furniture such as armchairs, couchs, tables, chairs, coffee tables, buffets and bedsteads are used in modern Turkish houses like Ottoman houses which were influenced by Westernization in the $19^{\text {th }}$ century when the interior furniture employed in modern Turkish houses are evaluated. Furthermore, approach of set and group continues in sitting and sleeping group furniture.

"It is observed that the styles used between 2000 and 2010 in $21^{\text {st }}$ century Turkish house interior designs are rationalism and eclectism" (Arslan Dinçay, 2014:194). "The eclectic interior, is the preference of wannabe new-rich individuals without culture whose ethics level is low. On the other hand, rationalism represents a statue of high education in 2010" (Arslan Dinçay, 2014:195). It is observed that modernism has stood out in interior design plans after 2010 (Tuzlu Erol, 2013: 67-110).

\section{COMPARISON OF INTERIOR DESIGNS OF HOUSES BEFORE AND AFTER 19TH CENTURY WESTERNIZATION MOVEMENTS AND IN THE 21 ${ }^{\text {ST }}$ CENTURY}

Interior designs of Turkish houses before and after $19^{\text {th }}$ century Westernization movements and $21^{\text {st }}$ century Turkish houses have been compared in terms of space organizations, furniture usage and interior design styles and the results obtained have been summarized as below in separate chapters.

\section{Comparison Of Interiors In Terms Of Space Organizations}

As it can be seen in Table 1, there was a change from multifunctional room approach to monofunctional room approach in the houses with the influence of the $19^{\text {th }}$ century Westernization movement. In addition, it is understood that this change has been maintained in the $21^{\text {st }}$ century Turkish houses and has continued even by increasing. 
Table 1. Comparison of interiors in terms of space organizations

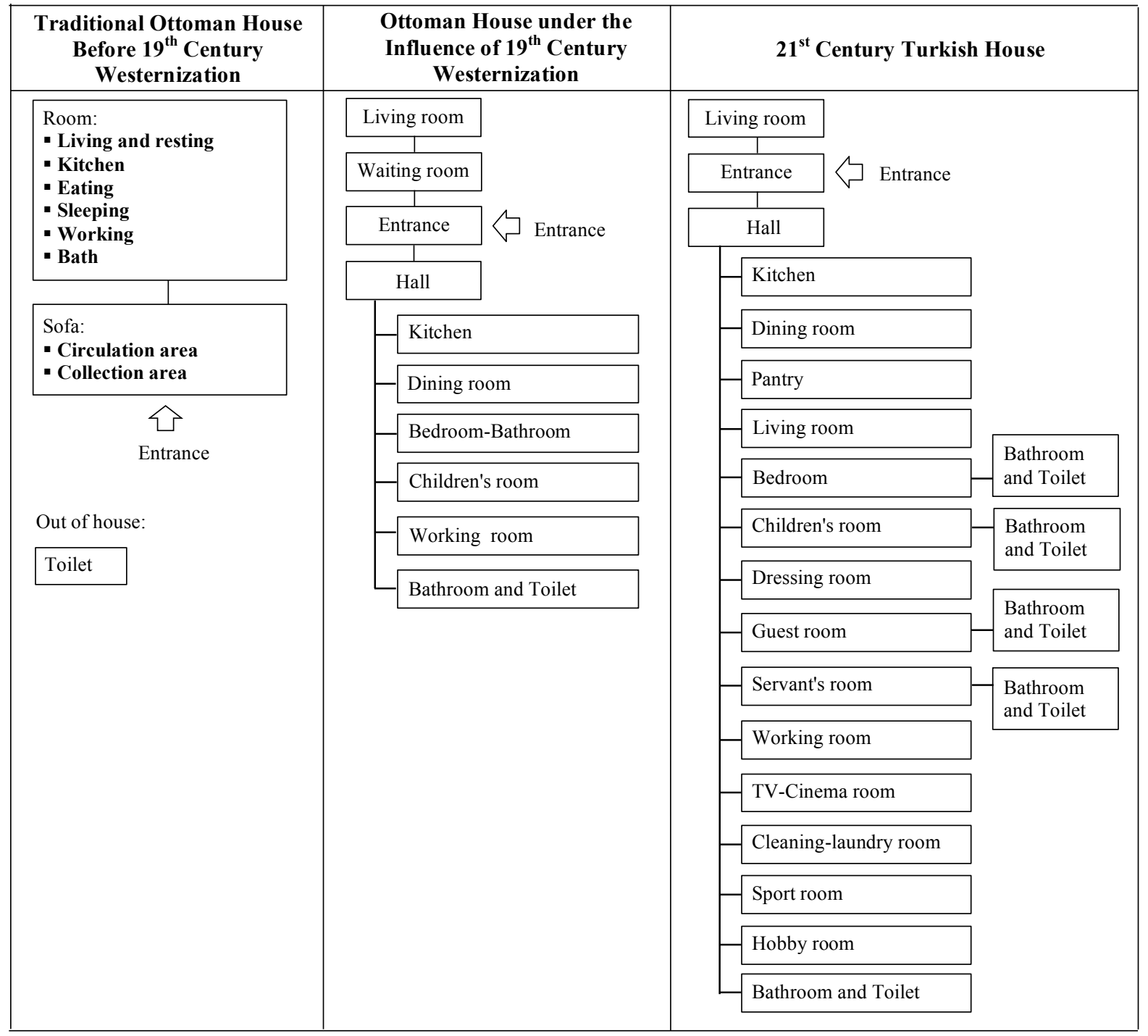

\section{Comparison Of Interiors In Terms Of Furniture Usage}

As it can be seen in Table 2, couch, chair and armchair replaced sedir of the traditional Ottoman house under the influence of Westernization and approach of usage of groups and sets in furniture has become outstanding. Furthermore, in this period Western-style furniture such as console, buffet, coffee table, mid table etc. have been used. Dining table, chair and buffet were started to be used in the dining room while a bedstead instead of a floor bed in the bedrooms and wardrobe, nightstand and chest of drawers were used instead of yüklük.It is observed that the furniture usage way created by the impact of Westernization continues even today seen the appended in the $21^{\text {st }}$ century Turkish houses. 
Table 2. Comparison of interiors in terms of furniture usage

\begin{tabular}{|c|c|c|c|}
\hline Activities & $\begin{array}{l}\text { Traditional Ottoman } \\
\text { House Before 19th } \\
\text { Century Westernization }\end{array}$ & $\begin{array}{l}\text { Ottoman House under } \\
\text { the Influence of } 19^{\text {th }} \\
\text { Century Westernization }\end{array}$ & $\begin{array}{l}\text { 21 st Century } \\
\text { Turkish House }\end{array}$ \\
\hline Sitting & Sedir (Ottoman) & $\begin{array}{l}\text { Couch } \\
\text { Armchair } \\
\text { Chair }\end{array}$ & $\begin{array}{l}\text { Couch } \\
\text { Armchair } \\
\text { Chair }\end{array}$ \\
\hline Eating & Floor table & $\begin{array}{l}\text { Dinner table } \\
\text { Coffee table } \\
\text { Middle table } \\
\text { Chair } \\
\end{array}$ & $\begin{array}{l}\text { Dinner table } \\
\text { Coffee table } \\
\text { Middle table } \\
\text { Chair } \\
\end{array}$ \\
\hline Sleeping & Floor bed & Bedstead & Bed \\
\hline \multirow[t]{2}{*}{ Storage } & Yüklük (closet) & $\begin{array}{l}\text { Buffet } \\
\text { Console } \\
\text { Wardrobe } \\
\text { Nightstand } \\
\text { Chest of drawers } \\
\text { Cabinet }\end{array}$ & $\begin{array}{l}\text { Buffet } \\
\text { Console } \\
\text { Wardrobe } \\
\text { Nightstand } \\
\text { Chest of } \\
\text { drawers } \\
\text { Cabinet }\end{array}$ \\
\hline & $\begin{array}{l}\text { Sergen (high shelves) } \\
\text { Shelf } \\
\text { Niche }\end{array}$ & $\begin{array}{l}\text { Shelf } \\
\text { Niche }\end{array}$ & $\begin{array}{l}\text { Shelf } \\
\text { Niche }\end{array}$ \\
\hline
\end{tabular}

\section{Comparison Of Indoor Interiors In Terms Of Design Styles}

As it can be seen in Table 3, different styles such as Baroque, Regence, Rococo etc. are used in the Ottoman houses by the effect of $19^{\text {th }}$ century Westernization movement. It is understood that rationalism and eclecticism have come to the fore between 2000 and 2010 but after 2010 it has turned to a modern design concept similar to that of the traditional Ottoman house in $21^{\text {st }}$ century Turkish houses. In this context, it is observed that the styles used in interior design due to the influence of Westernization have completely disappeared in $21^{\text {st }}$ century Turkish houses.

Table 3. Comparison of interiors in terms of design styles

\begin{tabular}{|c|c|c|c|}
\hline \multirow{2}{*}{$\begin{array}{c}\text { Traditional } \\
\text { Ottoman House } \\
\text { Before 19th Century } \\
\text { Westernization }\end{array}$} & \multirow{2}{*}{$\begin{array}{c}\text { Ottoman House } \\
\text { under the Influence } \\
\text { of } 19^{\text {th }} \text { Century } \\
\text { Westernization }\end{array}$} & \multicolumn{2}{|c|}{$21^{\text {st }}$ Century Turkish House } \\
\hline & & $\begin{array}{c}\text { Between } 2000- \\
2010\end{array}$ & After 2010 \\
\hline Modernism & $\begin{array}{l}\text { Baroque } \\
\text { Regence } \\
\text { XV. Louis } \\
\text { XVI. Louis } \\
\text { Rococo } \\
\text { Neo classic } \\
\text { Orientalist } \\
\text { Art Nouveou }\end{array}$ & $\begin{array}{l}\text { Rationalism } \\
\text { Eclecticism }\end{array}$ & Modernism \\
\hline
\end{tabular}

\section{CONCLUSION}

Following issues have been observed as a result of the study carried out with a view to understand whether the influences created by the $19^{\text {th }}$ century Westernization movements in the Ottoman Empire in the housing interior design of that period, continues in the $21^{\text {st }}$ century Turkish houses:

- Change from multifunctional room concept of traditional Ottoman house to so monofunctional space understanding by the effects of Westernization continues by increasing in the $21^{\text {st }}$ century Turkish houses. 
- The style of using furniture and the approach of using sets and groups created by the influence of Westernization continues also in the $21^{\text {st }}$ century Turkish houses.

- The styles used in the interior design by the influence of Westernization have completely been eliminated in the $21^{\text {st }}$ century Turkish houses and return to the modern design concept in the traditional Ottoman house has begun.

\section{ACKNOWLEDGEMENTS}

I would like to extend my thanks to Rüya Sezek, the teacher of World History in IELEV Private High School.

\section{References}

Algan, Ö. (2006) 19.Yüzyıl Batılılaşma Etkisiyle Osmanlı Sarayına Giren Mobilyanın Gelişimi: Dolmabahçe Sarayı Örneği, Thesis, Kocaeli University.

Arslan Dinçay, D. (2014) 1960-2010 Yılları Arasında İstanbul kentli Konut İç Mekan Düzenlemelerini Türk Sineması Üzerinden Okumak. Dissertation. Istanbul Technical University. Available at: https://tez.yok.gov.tr/UlusalTezMerkezi/tezSorguSonucYeni.jsp (Accessed: 03 März 2018).

Artıkoğlu, P. (2011) 'Batılılaşma'nın Osmanlı Aile Yaşamındaki İzleri', 38. ICANAS Uluslararası Asya ve Kuzey Afrika Çalışmaları Kongresi. Atatürk Higher Institution of Culture, Language and History, 10-15 September 2007. Atatürk Higher Institution of Culture, Language and History, 1, pp. 47-58.

Bektaş, C. S.(2001) Halk Yapı Sanatı, Literatür Publisher, Istanbul.

Bozkurt Azezli, S.G. (2009) 19.Yy'da Osmanlı Konut Mimarisinde İç Mekan Kurgusunun Safranbolu Evleri Örneğinde İrdelenmesi, Thesis, Istanbul Kultur University.

Bozkurt, S. G. (2013). '19.yy da Osmanlı Konut Mimarisinde İç Mekan Kurgusunun Safranbolu Evleri Örneğinde İrdelenmesi', İstanbul University- Journal of Forestry Faculty, 62(2), pp.37-70.

Burkut, E.B. (2014). Osmanlı/Türk Evi Mekân Kurgusunu Modern Konut Mimarisinde Okumak (Wright, Corbusier, Eldem ve Cansever'in Konutları), Thesis, Fatih Sultan Mehmet Foundation University. Available at: https://tez.yok.gov.tr/UlusalTezMerkezi/tezSorguSonucYeni.jsp (Accessed: 03 March 2018).

Demirarslan, D. (2011) 'Batılılaşma Sürecinde Türk Barınma Kültüründeki Değişim ve Konuttaki Yansımaları', 38. ICANAS International Congress of Asian and North African Studies, Atatürk Higher Institution of Culture, Language and History, 10-15 September 2007, 1,pp. 209-220.

Eldem, S. H. (1987) Osmanlı Dönemi Türk Evi, Istanbul: III. Turkey Monuments Foundation of the Protection EcoTourism Value, pp. 13, 15, 18, 80, 87-88, 128.

Göğebakan, Y. (2015) 'Karakteristik Bir Değer Olan Geleneksel Türk Evi’nin Oluşumunu Belirleyen Unsurlar ve Bu Evlerin Genel Özellikleri', İnönü University Cultur and Art Journal, 1(1), pp. 41-55.

Günay, R. (1998) Türk Ev Geleneği ve Safranbolu Evleri, Istanbul: YEM Publisher.

Hacıbaloğlu, M. (1989) Geleneksel Türk Evi ve Çağımıza Ulaşamamasının Nedenleri, Ankara: Gazi University Technical Education Faculty Press.

Herzog, C. und Motika, R. (2000) 'Oriantalism, Alla Turca; Late 19th/Early 20th Century Ottoman Voyages into the Muslim Outback', Die Welt Des Islams, 40(2), pp. 139.

Meriç, N. (2000) Osmanlı'da Adab-ı Muaşeret: Gündelik Hayatın Değişimi, Istanbul: Kaknüs Publisher.

İnce, A. (2013) Eski Mut Evleri, Thesis, Selçuk University. Available at: https://tez.yok.gov.tr/UlusalTezMerkezi/tezSorguSonucYeni.jsp (Accessed: 14 March 2018).

Karabulut, M. (2016) ‘Osmanlı İmparatorluğu’nda 19. Yüzyılda Değişim Süreci, Sosyal ve Kültürel Durum', Mecmua-International Social Sciences Journal, 1 (2), pp. 46-65.

Kuban, D. (1976) Sanat Tarihimizin Sorunları, Istanbul: Çağdaş Publisher.

Küçükerman, Ö. (1985) Kendi Mekanının Arayışı İçinde Türk Evi (2. Baskı), Istanbul: Touring and Automobile Institution of Turkey.

Küçükerman, Ö. (2007) Türk Evi-Kendi Mekanının Arayışı İçinde (5. Baskı), Istanbul: Touring and Automobile Institution of Turkey. 
Laf Sözlük. (2018) Sofa nedir ne demektir? Kısaca anlamı. Available at:

https://www.lafsozluk.com/2017/08/sofa-nedir-ne-demektir-kisaca-anlami.html (Accessed: 14 April 2018).

Lewis, B. (2002) The Emergence of Modern Turkey, Oxford: Oxford University Publisher.

Seçer, F. (2006) Teknolojik Gelişmelerin Konut İç Mekan Tasarımına Etkisi ve Akıllı Evler, Thesis, Istanbul: Mimar Sinan Fine Arts University.

Tuzlu Erol, Y. (2013) 2000'li Yılların Değişen Yaşam Biçimlerinin Konut İç Mekanlarına Yansımasının İncelenmesi, İstanbul Örneği, Thesis, Marmara University. Available at:

https://tez.yok.gov.tr/UlusalTezMerkezi/tezSorguSonucYeni.jsp (Accessed: 03 March 2018).

Uluengin, N. Y. (1998) Osmanlı-Türk Sivil Mimarisinde Pencere Açıklıklarının Gelişimi, Istanbul: Building Industry Center Publisher.

Yıldırım, K. and Hidayetoğlu, M.L. (2009) 'Reflections in the Traditional Turkish House of Turkish life Culture', 4th International Turkısh Culture and Art Congress/Art Activity. Kahire-Ägypten, 02-07 November 2009. 